\title{
Effect of environmental variables on epiphyton in a pampean lake with stable turbid- and clear-water states
}

\author{
María Gabriela Cano ${ }^{1, *}$, María Adela Casco ${ }^{1}$, María Cristina Claps $^{2}$ \\ ${ }^{1}$ D. C. Ficología, Facultad de Ciencias Naturales y Museo, UNLP-CONICET, (1900) La Plata, Buenos Aires, Argentina \\ ${ }^{2}$ Instituto de Limnología, 'R. A. Ringuelet', CONICET, CCT La Plata, (1888) Florencio Varela, Buenos Aires, Argentina
}

\begin{abstract}
In the present study, we examined the variation in composition and biomass of epiphyton growing on the bulrush Schoenoplectus californicus in a pampean lake that passed through a turbid- and a clear-water period within an annual cycle. Monthly sampling was performed year-round at the center and periphery of a bulrush stand. We measured the physicochemical parameters in the water column using standardized field and laboratory methods. The epiphyton was sampled by sectioning bulrush stems into segments for pigment analysis, abundance measurements, and biovolume quantification. Two different types of communities were observed during the annual cycle. In the turbid-water period, epiphyton biomass and diversity remained low despite sufficient levels of phosphates. An abrupt increase in epiphyton biomass, along with structural changes in the community, occurred after an improvement in water transparency, suggesting that the epiphyton was strongly dependent on underwater light conditions. Differences in epiphyton composition and biomass between the center and the periphery of the bulrush stand were negligible. We conclude that the availability of colonizing surface is not a relevant driver for the colonization and growth of these epiphyton assemblages. The epiphyton in pampean lakes may remain stable and resilient for relatively long periods, even when confronted with environmental perturbations, and changes in these communities will only occur in relation to radical alterations in light and nutrient availability.
\end{abstract}

KEY WORDS: Bulrush - Algal epiphyton - Pampean lakes · Argentina $\cdot$ Light climate $\cdot$ Total phosphorus $\cdot$ Community resilience

\section{INTRODUCTION}

The role of substrate-associated communities as fundamental components of aquatic ecosystems is recognized (Strayer \& Likens 1986, Boero et al. 1996, Goldsborough \& Robinson 1996, Polis et al. 1997, Vadeboncoeur et al. 2002, Schindler \& Scheuerell 2002, Vander Zanden et al. 2006). Over the past $30 \mathrm{yr}$, various authors have investigated periphytic community structure and dynamics over space and time in temperate lakes (Cattaneo \& Kalff 1980, Jones \& Mayer 1983, Kairesalo 1983,
Roos 1983a,b, Albay \& Akcaalan 2003, Liboriussen \& Jeppesen 2006, Poulícková et al. 2006) and in subtropical lakes (Meerhoff et al. 2007, Sánchez et al. 2010, Rodríguez et al. 2011). A few studies examining the relationships between epiphyton and water quality have also been carried out (Hansson 1992, Lowe 1996, Romo \& Galanti 1998). In the pampean region, only a few studies investigating periphytic communities in shallow lakes (Cano 2009, Cano et al. 2008, Dos Santos et al. 2008, Sánchez et al. 2010) have been conducted during the last decade. 
In pampean lakes, the emergent macrophyte Schoenoplectus californicus (Meyer) Soják (hereinafter referred to as 'bulrush') provides a more consistent substrate for periphyton colonization than submerged macrophytes. Batter may decline during the winter and thus constitute a seasonal substrate. Bulrush is a fundamental component of the shallow lakes, extending from southern North America to the Patagonia region (Tur \& Rossi 1976).

Cano et al. (2008) and Cano (2009) have shown that in Lacombe Lake (a shallow pampean lake), the epiphyton growing on emergent and submerged macrophytes is the greatest contributor to the total algal biomass, when expressed relative to the lake surface area. Epiphyton was found to account for 53 to $94 \%$ of the total algal biomass in summer, in contrast to the lower biomass of phytoplankton and epipelon (Cano et al. 2008). Thus, epiphyton can be considered a key component within the ecosystem of pampean shallow lakes in terms of algal primary production.

Two different states or phases of stable equilibrium, sensu Scheffer et al. (1993), were recognized in Lacombe Lake during this year-long study (Casco et al. 2009). Phase 1, the organic-turbid phase, extended from winter to early spring (July through September) and was characterized by the absence of submerged macrophytes along with high turbidity levels due to elevated phytoplanktonic densities. Phase 2, a clear-water phase, was detected subsequent to heavy rainfalls in October; after this precipitation, the nutrient concentrations increased, and the submerged macrophytes developed. Cano et al. (2009) described a third phase, characterized by a high water transparency and an extensive reduction in the coverage area of submerged macrophytes, especially in the center of the lake, following heavy rainfall in March.

The basic ecology of phytoplankton and epipelon in Lacombe Lake has already been described (Cano et al. 2008, Casco et al. 2009). Changes in the phytoplankton community closely followed the variations in the ecosystem, passing through the 3 states, but the epipelon remained in a constant condition, always dominated by shade-tolerant algae (Casco et al. 2009). Variations in the abundance and comosition of the epiphyton of Lacombe Lake in relation to seasonal changes and the 3 phases described above has, however, not yet been investigated.

In the present study, we analyzed the composition and examined the response of the epiphyton community to changes in environmental variables within the context of the alternating stable states of Lacombe Lake over 1 yr. We hypothesized that the epiphyton as a whole is primarily influenced by abiotic variables and would thus closely reflect the changes occurring within the ecosystem.

\section{MATERIALS AND METHODS}

\section{Study site}

Lacombe Lake $\left(35^{\circ} 50^{\prime} \mathrm{S}, 57^{\circ} 53^{\prime} \mathrm{W}\right)$ is located in the province of Buenos Aires in a pericoastal zone that extends into the pampean region. Lacombe Lake is a shallow eutrophic seepage lake, almost circular, covering 130 ha of surface area (Fig. 1). During the sampling period, from July 2001 through June 2002, the maximum and minimum depths were 2.5 and $1.7 \mathrm{~m}$, respectively (the mean depth from the 12 monthly depth measurements was $2.2 \mathrm{~m}$ ). More information has been detailed by Cano et al. (2008) and Casco et al. (2009). Most of the lake area is colonized by dense stands of emergent bulrush Schoenoplectus californicus and the submerged macrophytes Stuckenia striata (Ruiz \& Pavon) Holub and Myriophyllum quitense Kunth (Cano et al. 2008). The lake is exposed to a marginal degree of human disturbance through sport fishing and low-density cattle breeding.

\section{Sampling methods}

Sampling was performed every 4 wk at 2 sites (Fig. 1): Stn 1 at the center of a bulrush stand and Stn 2 at the periphery of the emergent-macrophyte beds. These sampling points differed mainly in the density of stems. Stn 1 had a higher density and a lower degree of exposure to environmental variables (predominantly wind and wave action) than Stn 2.

At each sampling station, the chemical and physical characteristics of the water (temperature $\left[{ }^{\circ} \mathrm{C}\right]$, $\mathrm{pH}$, turbidity [NTU], conductivity $\left[\mu \mathrm{S} \mathrm{cm}^{-1}\right]$, and dissolved oxygen concentration, $\left[\mathrm{mg} \mathrm{l}^{-1}\right]$ ) along a 5-level depth profile were recorded with a Horiba U 10 multiparametric sensor. We also collected water samples for chemical analysis and phytoplankton/chlorophyll a (chl a) quantification along this same profile and estimated the water transparency with a Secchi disk. The data for water turbidity, together with total suspended solids and macrophyte abundances, were used to characterize the light climate within the water column.

The bulrush density (stems $\mathrm{m}^{-2}$ ) and the cover $(\%)$ of submerged macrophytes were estimated from 


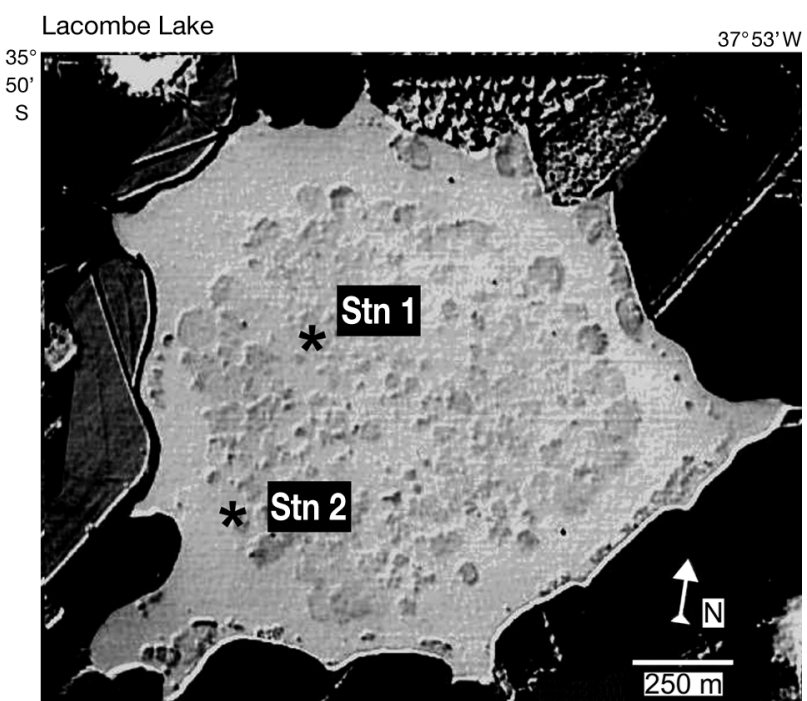

Fig. 1. Lacombe Lake sampling sites. The darker grey areas in the body of water correspond to higher bulrush densities

observations carried out in 10 random $1 \mathrm{~m}^{2}$ areas on each sampling occasion and at each site. The average surface that a bulrush stem can provide to the epiphytes for their establishment was represented as the submerged-epiphyte colonization surface (SECS) per stem. This value was calculated using the formula for the area of the frustum of a right cone.

All of these methods, together with the techniques for the laboratory analyses of total suspended solids, particulate organic matter, total phosphorus (TP), soluble reactive phosphorus, total inorganic nitrogen, reactive silica, and planktonic chl a have been detailed by Cano (2009), Cano et al. (2008), and Casco et al. (2009).

\section{Epiphyton sampling and processing}

We sampled for epiphyton by cutting 4 bulrush stems into $7 \mathrm{~cm}$ sections in a fixed 7 -level discontinuous vertical profile, beginning at the first centimeter below the surface of the water (using 4 replicate stems at each level). We selected by visual inspection only fully developed, non-senescent bulrush stems that had not been damaged by fungi or invertebrates. Every sample was placed in a flask with potable (municipal) tap water, transported to the laboratory at 5 to $8^{\circ} \mathrm{C}$ in the dark, and thereafter stored under the same conditions until analysis the following day.

Two replicates from each section were used for photosynthetic-pigment quantification and the other 2, fixed with $4 \%$ (v/v) aqueous Formalin ${ }^{\mathrm{TM}}$, were used for the quantification of epiphyte abundance and biovolume. Periphytic algae were scraped with a cover slip into a Petri dish. The slurry obtained from the 2 replicates of each section was filtered through Whatman GF/C filters in the dark, and the pigment extraction was carried out with $90 \%$ (v/v) aqueous acetone. Spectrophotometric measurements were taken before and after acidification, as detailed by Cano et al. (2008). The chl $a$ and phaeopigment concentrations were calculated according to Varela (1981). A pigment index was used to estimate the physiological condition of the algae (Ramírez 2005) and was defined as the quotient [(chl a concentration)/(chl a concentration + phaeopigment concentration)] $\times 100$, with the result expressed as a percentage.

The microscopic quantification of epiphytes involved 2 different preparative methods. (1) For single-layered communities, after a thorough description was made of the appearance of the communities under a stereoscopic microscope, the epiphytes were scraped off into a flask and washed with tap water. Depending on the quantity of epiphyton, the sample concentration was adjusted to a convenient dilution volume $(\sim 50 \mathrm{ml})$ for quantification. The sample was then dispersed by magnetic stirring, and a $200 \mu \mathrm{l}$ aliquot was placed in a Sedgwick-Rafter chamber. (2) For multilayered communities, dispersion was impossible because of the intertwining of these forms during stirring. Thus, quantification was carried out by first identifying the particular physiognomies of the different algal assemblages under the stereoscopic microscope and then estimating a percentage of coverage for each of them. A determined area of each physiognomy was finally removed with fine forceps and placed between a slide and a $1.8 \times 1.8 \mathrm{~cm}^{2}$ cover slip.

Quantification, using the Sedgwick-Rafter chamber, was performed in random fields (Rott 1981) until the minimal area for each sample was reached (Modenutti \& Balseiro 1995). For the slide counts-those involving an examination of at least $50 \%$ of the slide surface along strips - the densities were estimated by calculating the percentage of the total area occupied by each physiognomy, as has been fully detailed by Cano (2009). In both methods, a magnification of $400 \times$ was used for the smallest organisms (up to $40 \mu \mathrm{m}$ ) and $200 \times$ for the larger ones (Rott 1981); no fewer than 400 individuals per sample were counted, to give an error $\leq 10 \%$ in the quantifications (Lund et al. 1958).

Abundance (ind. $\mathrm{m}^{-2}$ of substrate) of micro- and macroinvertebrates was recorded at each degree of magnification. A verification of grazing by macroin- 
vertebrates on the periphyton (as indicated by snail trails or gaps in the periphyton mat) was made by observing the bulrush sections under a stereoscopic microscope.

We expressed algal densities as the number of individuals $\mathrm{cm}^{-2}$ of substrate, considering each colony and each filament as an individual. In both instances, the delimitation of individuals was problematic; thus, a so-called natural counting unit (Acker 2002) had to be adopted for each particular species (e.g. Aphanocapsa holsatica with 50 cells $=1$ individual). Only live organisms, identified as living according to Burkholder \& Wetzel (1989), were quantified.

During the quantification, size measurements were taken for biovolume calculations. When a species showed a wide range of sizes, the biovolumes were calculated according to size classes (Rott 1981). The average biovolume of each species was estimated for each sampling date.

Algal pigment concentrations, abundances, and biovolumes were expressed in $\mathrm{cm}^{2}$ of substrate. The area of each section of stem was determined using the formula for the frustum of a right cone.

The Shannon-Wiener diversity index $\left(H^{\prime}\right.$, see Margalef 1974) and Pielou's evenness index $\left(J^{\prime}\right)$ were calculated from the epiphyton density and from the total number of species recorded on the entire stem surface of all of the plants at each site on each sampling occasion.

The epiphyton was characterized based on the average data from each vertical profile. According to the preliminary values, the communities had a higher biomass and species richness at the portions of stems between the depths of 29 to $36 \mathrm{~cm}$. Thus, when the physiognomy and architecture were characterized, the data from this sector of the stem were used as representative of the composition of a welldeveloped community.

\section{Statistical analysis}

Except for transparency, the mean values of the 5-level vertical profile of water physicochemical parameters and planktonic chl a concentrations were used in all of the tests (Cano et al. 2008). Whenever necessary, the data were transformed to $\log _{10}(x+1)$ values or to square roots to meet the assumptions of the form of the parametric statistical analysis used.

The relationship between the water-quality variables and the sites was tested using principalcomponent analysis (PCA) with MVSP 3.1 (Kovach Computing Services).
The differences between the epiphyton variables in the samples from the 2 sites were tested using either 1-way ANOVA, when the normality and variance-homogeneity assumptions had been met by the raw or transformed data, or a Mann-Whitney nonparametric $U$-test, when the data could not be made to meet those assumptions. Both tests were performed with SPSS 8.0.

The differences between the epiphyton variables in the samples from different periods were tested using an ANOSIM analysis. These data were transformed (square root or $\log _{10}$ ) and standardized. The normalized Euclidian distance was used as the similarity index, and 10000 permutations were run to calculate the significance level of the sample statistic R. The analysis was carried out using PRIMER 5.2.9.

The epiphyton variables were then correlated with the sample scores of the first and second axes of the environmental PCA analysis using a nonparametric Spearman correlation index $\left(\mathrm{r}_{\mathrm{S}}\right)$ to relate the epiphyton parameters to the environmental dynamics using SPSS 8.0.

\section{RESULTS}

\section{Environmental variables}

The sampling period was characterized by 3 heavy rainfalls: August 2001 (191 mm), October 2001 (223 mm), and March 2002 (515 mm; this last rainfall being the highest monthly record in the previous 25 yr). Soon after each rainfall, we recorded increases in the hydrometric levels (Fig. 2a). The resulting greater water volumes, in turn, were accompanied by decreases in the conductivity and ion concentrations. In contrast, the evaporation occurring during the following summer produced a drop in water levels that elevated these variables.

Changes also resulted in the SECS per stem in relation to variations in the hydrometric level and increases in stem diameter throughout bulrush growth (Fig. 2b). Bulrush density was higher at Stn 1 ( 9 to 81 stems $\mathrm{m}^{-2}$ ) than at $\mathrm{Stn} 2$ (5 to 17 stems $^{-2}$ ) throughout most of the study period. At Stn 1, the densities started to increase in October, reached a maximum in February, and then decreased after the heavy rainfalls in March. At Stn 2, the densities were relatively low on all of the sampling occasions (Fig. 2b).

Marked variations in the development of submerged macrophytes were recorded in October and March. The plants started to grow in October, reaching the maximum percent coverage in January (13 

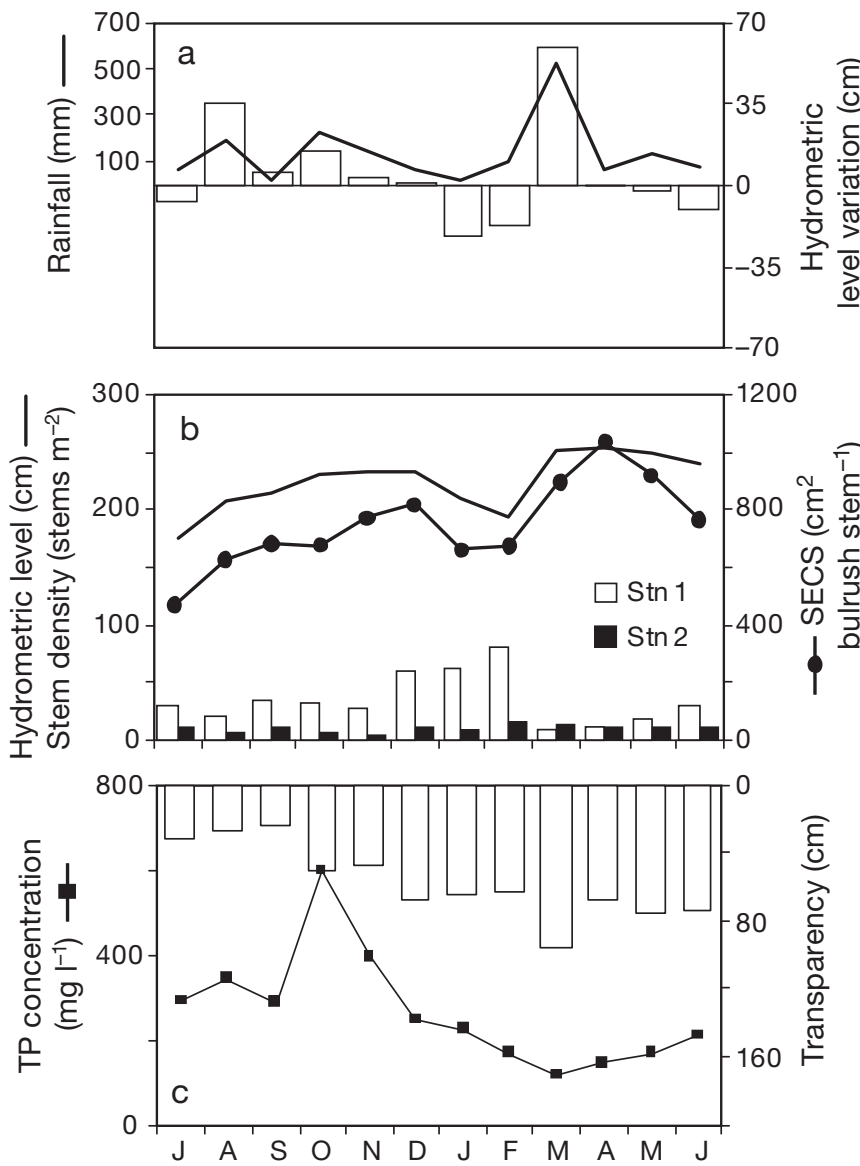

Fig. 2. Environmental variables at Lacombe Lake during the analyzed annual cycle. (a) Water level at Stn 1 corresponding to monthly precipitation levels; (b) submerged epiphyte colonization surface (SECS) corresponding to water levels at Stn 1 as well as the stem density at Stn 1 and Stn 2; (c) transparency and total phosphorus (TP) concentrations

and $50 \%$ at Stn 1 and Stn 2, respectively). In March, a severe reduction in the macrophyte stands in the deeper zones left the stands near the shores as the remaining plants but at a lower density coincident with the elevation in the water level.

After the October and March precipitation events, changes in most of the environmental and biological variables occurred, particularly an increase in the TP concentrations in October (Fig. 2c). The TP values at both sites varied from 286 to $289 \mu \mathrm{g} \mathrm{P}^{-1}$ from July

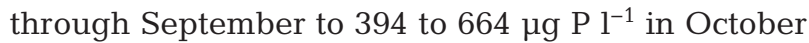
and November. Afterward, the concentrations dropped to 101 to $249 \mathrm{\mu g} \mathrm{P}^{-1}$ from December through February. The March input of a large volume of rainwater was associated with the minimum TP values observed in the study (95 to $102 \mu \mathrm{g} \mathrm{P}^{-1}$ ). From September to October, a drop in phytoplankton chl a concentration from 64.1 to $65.5 \mathrm{mg} \mathrm{m}^{-3}$ to 6.7 to $14 \mathrm{mg} \mathrm{m}^{-3}$ was also recorded at both of the sites. During Octo- ber, the increase in water transparency (Fig. 2c) and diminution in suspended-solid concentrations were related to the decrease in phytoplankton biomass.

The physicochemical parameters recorded at both of the sampling stations throughout the year were similar (Table 1).

The changes recorded in the shallow lake during the study period were well reflected in the PCA biplot (Fig. 3) constructed from the mean values per site per sampling occasion. The variables that had the greatest contributions on the first axis (accounting for $55 \%$ of the variance) were the transparency on the positive sector and the suspended solids, TP, and conductivity on the negative sector. Temperature and $\mathrm{pH}$ contributed the most to the positive sector of the second axis (accounting for $24 \%$ of the variance). The samples distributed along the first axis fell mainly into 3 groups: (1) July through September, (2) October through February, and (3) March through June. The distribution of the samples among these monthly periods coincided with changes in the variables used for the ordination, i.e. from turbid to transparent water and from higher to lower conductivity and TP concentrations. In contrast, the ordination of the samples on the second axis coincided with the changes in the temperature and the $\mathrm{pH}$. The spring and summer samples were located on the positive sector of this axis. The samples collected in June, because of lower temperature and $\mathrm{pH}$ values, became separated from the rest (Fig. 3). The third axis gathered the variation resulting from the TP levels (accounting for $17 \%$ of the variance).

\section{Epiphyton: general trends}

A total of 145 taxa were identified, with $36 \%$ belonging to the Chlorophyta, $32 \%$ to the Heterokontophyta (mostly the Bacillariophyceae), $28 \%$ to the cyanobacteria, and the rest to the Euglenophyta (3\%) and Dinophyta (1\%).

The minimum total species richness (on the basis of all of the species found along the vertical profile) occurred during the first 4 mo. The species richness increased in November, with the higher values in the following months (50 to 70 species) related to an increase in the number of species from the 3 dominant groups (cyanobacteria, Chlorophyta, and Bacillariophyceae; Fig. 4a).

The average density increased during October and November (up to $9.30 \times 10^{5}$ ind. $\mathrm{cm}^{-2}$ at Stn 1 and $8.48 \times 10^{5}$ ind. $\mathrm{cm}^{-2}$ at Stn 2). During the rest of the sampling period, this variable ranged between 
Table 1. Environmental variables at Stn 1 and Stn 2 during the study period. The calculations were performed including all values registered in each profile level on all sampling occasions. $\mathrm{n}=60$ in all instances, except for the Secchi depth $(n=12)$

\begin{tabular}{|c|c|c|c|}
\hline Variable & Stn & Mean (range) & $\mathrm{SD}$ \\
\hline Water temperature $\left({ }^{\circ} \mathrm{C}\right)$ & $\begin{array}{l}1 \\
2\end{array}$ & $\begin{array}{l}17.7(9.8-26.9) \\
17.5(9.7-27.9)\end{array}$ & $\begin{array}{l}5.2 \\
5.3\end{array}$ \\
\hline Conductivity $\left(\mu \mathrm{S} \mathrm{cm}^{-1}\right)$ & $\begin{array}{l}1 \\
2\end{array}$ & $\begin{array}{l}2380.0(1310.0-4170.0) \\
2356.0(1290.0-4130.0)\end{array}$ & $\begin{array}{l}811.0 \\
807.0\end{array}$ \\
\hline $\mathrm{pH}$ & $\begin{array}{l}1 \\
2\end{array}$ & $\begin{array}{l}9.8(8.5-10.4) \\
9.7(8.5-10.3)\end{array}$ & $\begin{array}{l}0.4 \\
0.4\end{array}$ \\
\hline Secchi depth (cm) & $\begin{array}{l}1 \\
2\end{array}$ & $\begin{array}{c}57.4(25.0-95.0) \\
61.0(30.0-100.0)\end{array}$ & $\begin{array}{l}21.0 \\
22.0\end{array}$ \\
\hline Turbidity (NTU) & $\begin{array}{l}1 \\
2\end{array}$ & $\begin{array}{l}42.0(13.0-118.0) \\
44.0(10.0-180.0)\end{array}$ & $\begin{array}{l}34.0 \\
43.0\end{array}$ \\
\hline Dissolved oxygen $\left(\mathrm{mg} \mathrm{l}^{-1}\right)$ & $\begin{array}{l}1 \\
2\end{array}$ & $\begin{array}{l}8.4(1.3-11.8) \\
8.8(3.2-13.6)\end{array}$ & $\begin{array}{l}1.9 \\
1.7\end{array}$ \\
\hline $\begin{array}{l}\text { Total suspended solids } \\
\left(\mathrm{mg} \mathrm{l}^{-1}\right)\end{array}$ & $\begin{array}{l}1 \\
2\end{array}$ & $\begin{array}{l}25.8(7.5-100.0) \\
29.5(3.2-132.0)\end{array}$ & $\begin{array}{l}24.2 \\
34.4\end{array}$ \\
\hline $\begin{array}{l}\text { Particulate organic } \\
\text { matter }\left(\mathrm{mg} \mathrm{l}^{-1}\right)\end{array}$ & $\begin{array}{l}1 \\
2\end{array}$ & $\begin{array}{l}21.8(6.4-94.3) \\
23.7(3.2-99.0)\end{array}$ & $\begin{array}{l}20.9 \\
26.5\end{array}$ \\
\hline Total phosphorus $\left(\mu g \mathrm{l}^{-1}\right)$ & $\begin{array}{l}1 \\
2\end{array}$ & $\begin{array}{c}267.0(102.0-664.0) \\
260.0(95.0-595.0)\end{array}$ & $\begin{array}{l}134.0 \\
122.0\end{array}$ \\
\hline $\begin{array}{l}\text { Soluble reactive phosphorus } \\
\left(\mu \mathrm{g} \mathrm{l}^{-1}\right)\end{array}$ & $\begin{array}{l}1 \\
2\end{array}$ & $\begin{array}{l}29.2(10.2-131.4) \\
29.3(9.0-138.6)\end{array}$ & $\begin{array}{l}33.2 \\
35.3\end{array}$ \\
\hline $\begin{array}{l}\text { Total inorganic nitrogen } \\
\left(\mu \mathrm{g} \mathrm{l}^{-1}\right)\end{array}$ & $\begin{array}{l}1 \\
2\end{array}$ & $\begin{array}{l}552.0(159.0-1132.0) \\
544.0(184.0-1239.0)\end{array}$ & $\begin{array}{l}263.0 \\
262.0\end{array}$ \\
\hline Reactive silica (mg l${ }^{-1}$ ) & $\begin{array}{l}1 \\
2\end{array}$ & $\begin{array}{l}9.9(0.3-60.2) \\
9.5(0.2-58.0)\end{array}$ & $\begin{array}{l}14.6 \\
14.5\end{array}$ \\
\hline $\begin{array}{l}\text { Planktonic chlorophyll a } \\
\left(\mu \mathrm{g} \mathrm{l}^{-1}\right)\end{array}$ & $\begin{array}{l}1 \\
2\end{array}$ & $\begin{array}{c}33.4(1.3-155.9) \\
33.1(3.1-85.0)\end{array}$ & $\begin{array}{l}27.4 \\
23.4\end{array}$ \\
\hline
\end{tabular}

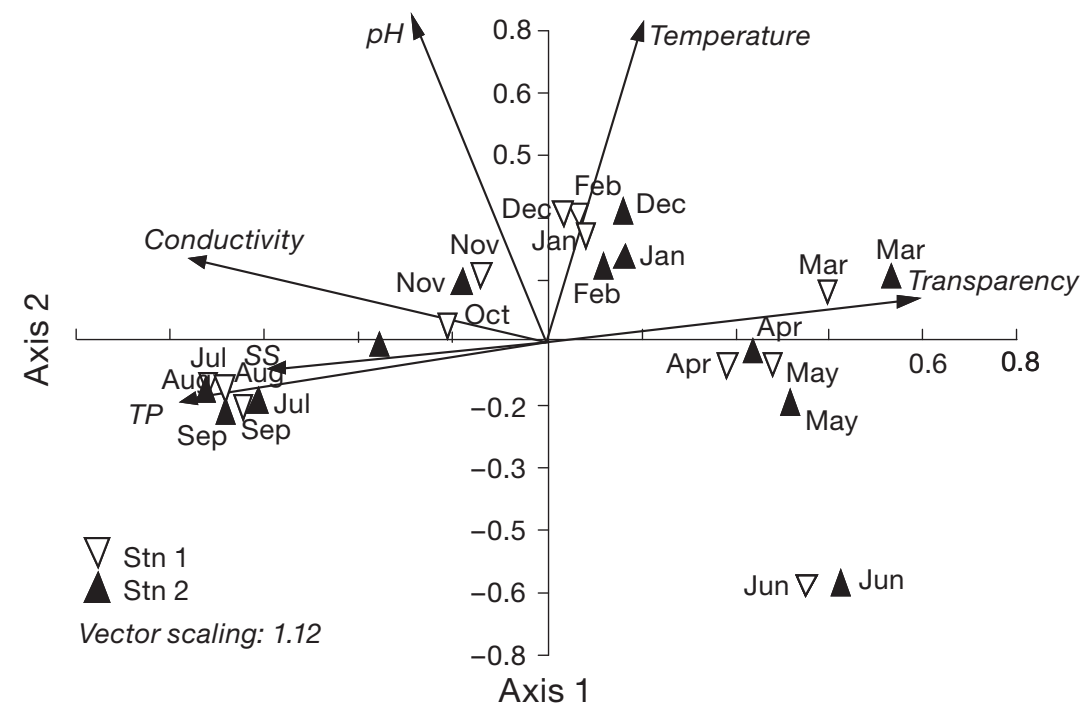

Fig. 3. Principal component analysis. Sample ordination according to selected environmental variables (in italics). TP: total phosphorus; SS: suspended solids
$6.10 \times 10^{4}$ and $2.68 \times 10^{3}$ ind. $\mathrm{cm}^{-2}$ in both statistics. The density values in February at Stn 2 (Fig. 4b) resulted from the development of filamentous taxa, such as Spirogyra and Oedogonium, and coincided with the highest average total biovolume $\left(11.4 \times 10^{9} \mathrm{um}^{3} \mathrm{~cm}^{-2}\right.$, Fig. $\left.4 \mathrm{c}\right)$. The total biovolume was lowest from July through September ( 0.14 to $0.33 \times 10^{9} \mu^{3} \mathrm{~cm}^{-2}$ ) and then tended to increase for the rest of the sampling period, especially through the more abrupt increments of October and April immediately after the heavy rainfalls (Fig. 4c). Although a marked increment in the average total biovolume was observed in October, an increase in the average biovolume per individual was not recorded until December (Fig. 4d). This parameter reached its maximum values for Stn 1 in March $\left(2.69 \times 10^{4} \mu^{3}\right.$ ind..$\left.^{-1}\right)$ and for Stn 2 in May $\left(3.03 \times 10^{4}{\mu \mathrm{m}^{3}}^{3}\right.$ ind..$^{-1}$ ).

The chl a concentration exhibited lower values during the winter ( 0.2 to $1.3 \mu \mathrm{g}$ $\mathrm{cm}^{-2}$ ) but then increased in October to become almost 57 -fold higher than in September and at that time constituted the maximum value for the entire study period (9.3 and $10 \mu \mathrm{g} \mathrm{cm}^{-2}$ at Stns 1 and 2, respectively). Thereafter, from November on, the chl a concentrations ranged from 2.1 to $5.8 \mu \mathrm{g} \mathrm{cm}^{-2}$ (Fig. $4 \mathrm{e}$ ). The phaeopigment concentrations were low at both sites (maxima at 2.4 and $0.8 \mu \mathrm{g} \mathrm{cm}^{-2}$ for Stns 1 and 2, respectively) and generally higher at Stn 1 than at Stn 2. The pigment indices were $>80 \%$ on almost all occasions (Fig. 4f).

$H^{\prime}$ ranged from 1.16 (Stn 1 in August) to 2.92 (Stn 2 in January). The minimum and maximum $J^{\prime}$ were likewise recorded at these same sites and in those same months, at 0.33 and 0.72 , respectively. Lower values were observed from August to October, and higher values were found from November to March (Fig. 4g,h). This pattern is especially evident when these values are compared to the average diversity and evenness $\left(H^{\prime}=2\right.$ and $J^{\prime}=$ $0.5)$. After the heavy autumnal rainfalls, the 2 variables dropped to similar average values as at the beginning of the study in July. 


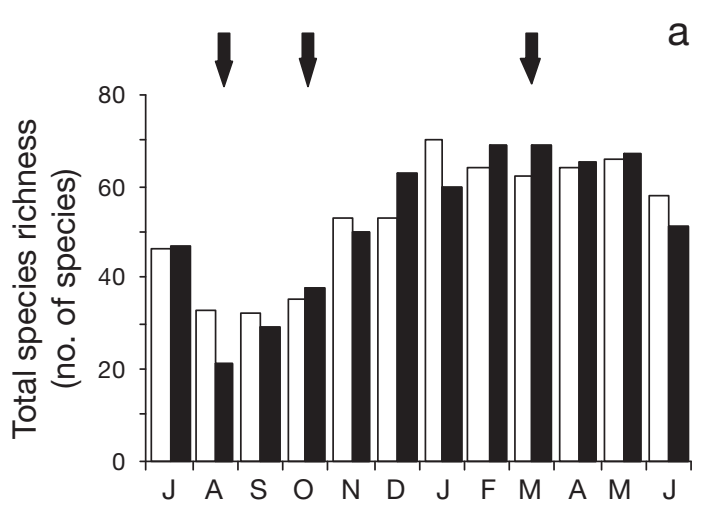

a
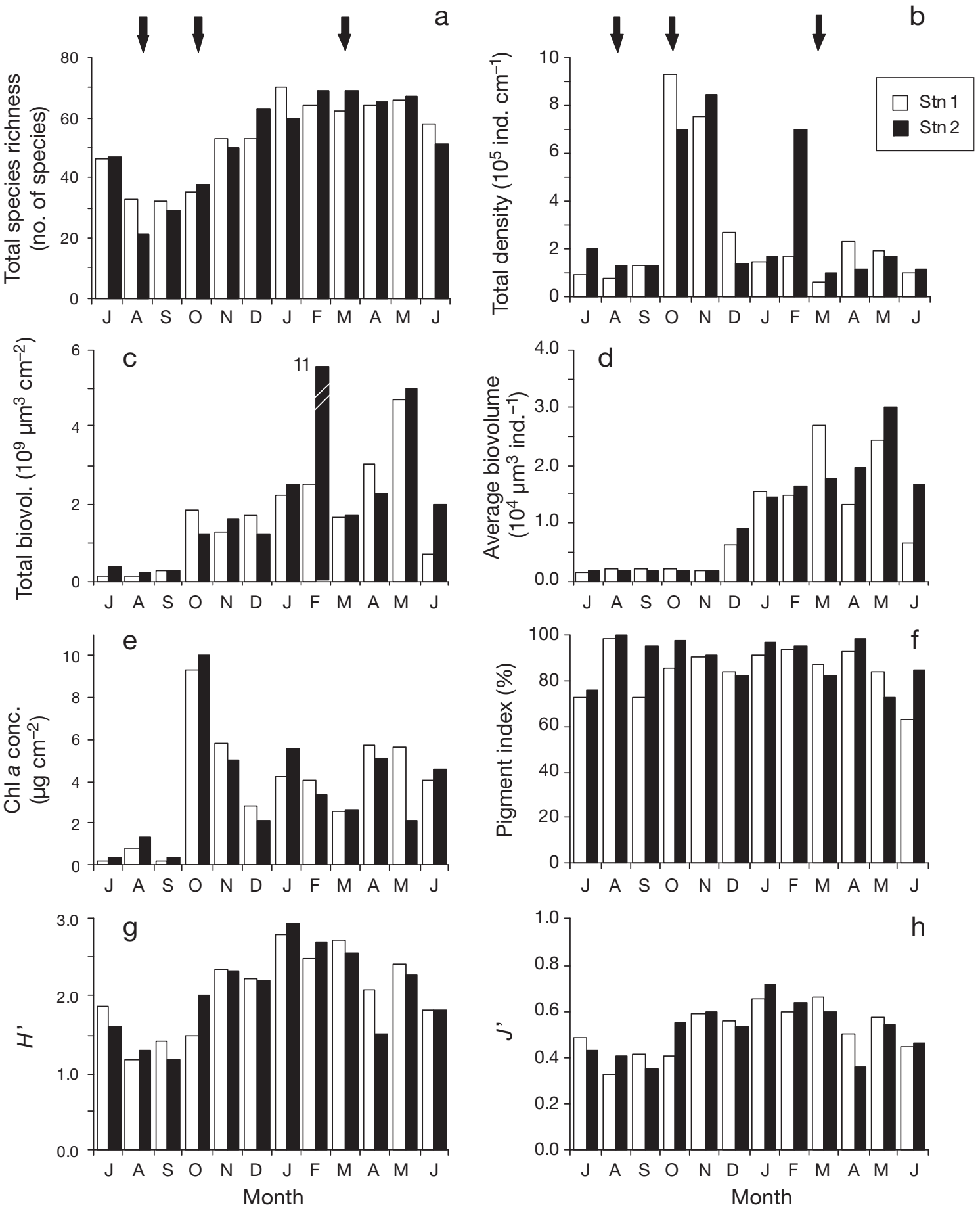

Fig. 4. Epiphyton descriptive variables: (a) total species richness (number of species), (b) total density, (c) total biovolume, (d) average biovolume per individual, (e) chlorophyll a concentration, (f) pigment index, (g) Shannon-Wiener index $\left(H^{\prime}\right)$, (h) Pielou's evenness index $\left(J^{\prime}\right)$. The values are for the average profile with respect to all variables except for $(\mathrm{a})$, $(\mathrm{g})$, and $(\mathrm{h})$. Rainfall events are marked with black arrows

In summary, the trends over the year recorded for the total species richness, total biovolume, average biovolume per individual, chl a concentration, $H^{\prime}$ and $J^{\prime}$ were all similar. For all of these variables, lower values were recorded during the first 3 or 4 mo of the study period and higher values starting in November or December. The density and the pigment index followed different patterns of variation.

The differences between the samples from Stn 1 and Stn 2 were neither graphically evident nor statis- 
tically significant. In particular, the 1-way ANOVA analyses performed with the total species richness $(F=0.01 ; \mathrm{p}=0.9)$, chl a $(F=0.04 ; \mathrm{p}=0.8)$ and phaeopigment concentrations $(F=1.53 ; \mathrm{p}=0.2)$, pigment index $(F=1.45 ; \mathrm{p}=0.2)$, and $H^{\prime}(F=0.02 ; \mathrm{p}=0.9)$ and $J^{\prime}(F=0.01 ; \mathrm{p}=0.9)$ indicated no significant differences between the sites $(p>0.05)$. Likewise, the Mann-Whitney $U$-test carried out with the total biovolume $(Z=0.29 ; \mathrm{p}=0.77)$, the average biovolume per individual $(Z=0.17$; $\mathrm{p}=0.86)$, and the total density $(Z=0.17 ; \mathrm{p}=0.86)$ was not significantly different between the 2 sites $(\mathrm{p}>0.05)$.

Although the overall properties of the communities at the 2 sites were not distinguished statistically, an evident contrast between the values during the first 3 mo and those of the rest of the study period could be observed graphically for the chl a concentration and the total biovolume (Fig. 4). The differences of the total species richness, $J^{\prime}$, and consequently $H^{\prime}$ were less marked but nevertheless evident. An ANOSIM test was therefore conducted to investigate whether the differences between these 2 time periods were significant. Upon consideration that the environmental variables showed differences among 3 periods (July through September, October through February, and March through June), instead of simply 2 periods, in relation to the 2 major rainfalls that occurred, a 1-way ANOSIM analysis was also designed to account for possible variation in the epiphyton parameters in the 3 periods. The independent variables selected for the analysis were the total species richness, total density, total biovolume, and chl a concentration. Although global R was low (0.28), the value was significant (significance level $=0.1 \%$ ), indicating that there were differences among the groups of samples tested. These differences were significant between the first period and both the second and the third periods (Period 1 vs. Period 2: $\mathrm{R}=0.4$, significance level $=0.9 \%$; Period 1 vs. Period $3: \mathrm{R}=0.7$, significance level $=0.01 \%$ ). In contrast, differences between the second and third periods were not significant $(\mathrm{R}=-0.04$, significance level $=63 \%)$. This result showed that the dynamics of the epiphyton variables followed-if only moderately - the turbidvs. clear-water periods but not the changes that occurred after the March rainfalls, as stated above.

This tendency was also verified when the data of different epiphyton variables were compared to the first-, second-, and third-axis PCA scores in Fig. 2. The total species richness, $H^{\prime}$, phaeopigment concentration, total biovolume, and the average biovolume per individual were significantly correlated $(\mathrm{p}<$ 0.05) with the scores of the first axis involving the decreasing tendencies in turbidity, conductivity, and TP levels. Density and the chl a concentration were strongly related to the sharp change in the TP levels occurring during October, as shown by the significant $r_{S}$ coefficients for the third-axis scores $(p<0.05$; Table 2).

The changes in biomass and diversity over time described above coincided with strong modifications in the physiognomies and compositions of the communities analyzed. Table 3 lists the presence or absence of the most abundant species by taxonomic group. From July to September, the epiphyton formed singlelayered associations, dominated by a complex of 2 Gomphonema species (i.e. the G. parvulum/G. gracile complex sensu Schoeman et al. 1984) characterized by growth on short stalks. In this architecture, colonies of Halamphora veneta (Kützing) Levkov and Cosmarium sociale Woronichin, along with short filaments of Heteroleibleinia pusilla (Hansgirg ex Hansgirg) Anagnostidis \& Komárek and thin filaments of Oedogonium sp. aff. sphaerandrum Wittrock \& Lundell were the principal structuring species. Then, as a result of the different changes in composition that occurred between October and November, the communities began to gain height, and multilayered physiognomies became observable up to the end of the study period. In these structures, large filaments of 2 species of Spirogyra (S. puncticulata Jao and Spirogyra sp. 2; Table 3) constituted an upper layer reaching a height of $25 \mathrm{~mm}$. Shorter filaments of Oedogonium inversum Wittrock and O. macrandrum Wittrock made up a middle layer, while numerous species of Bacillariophyceae, such as Nitzschia amphibia Grunow, Rhopalodia musculus (Kützing) Müller, R. gibba (Ehrenberg) Müller, H. veneta, and Mastogloia elliptica (Agardh) Cleve, together with several cyanobacteria-Nostoc punctiforme (Kützing) Hariot, Scytonema

Table 2. Nonparametric-correlation analysis. Spearman correlation coefficients for paired comparisons of the PCA scores of the first, second, and third axes with different epiphyton descriptive variables. ${ }^{*} \mathrm{p}<0.05 ;{ }^{* *} \mathrm{p}<0.01$

\begin{tabular}{|lccc|}
\hline & \multicolumn{3}{c|}{ Axis } \\
& 1 & 2 & 3 \\
\hline Species total richness & $0.75^{* *}$ & $0.47^{*}$ & -0.01 \\
Shannon-Wiener index $\left(H^{\prime}\right)$ & $0.53^{*}$ & $0.49^{*}$ & 0.12 \\
Pielou's evenness index $\left(J^{\prime}\right)$ & $0.47^{*}$ & $0.45^{*}$ & 0.11 \\
Total density & -0.17 & 0.37 & $0.58^{* *}$ \\
Active chl a conc. & 0.35 & 0.32 & $0.71^{* *}$ \\
Phaeopigment conc. & $0.69^{* *}$ & 0.07 & $0.49^{*}$ \\
Pigment index & -0.30 & 0.25 & 0.15 \\
Total biovolume & $0.66^{* *}$ & 0.38 & 0.24 \\
Avg. biovolume per ind. & $0.85^{* *}$ & 0.19 & -0.06 \\
\hline
\end{tabular}


Table 3. Species presence-absence data. Only the species that represented $5 \%$ or more of the total abundance of a sample belonging to either of the sites or any of the sections or sampling dates are considered. (+) present, (blank) absent. A species present in one place but not in the other is considered to be present (+). Growth form: (C) Colonial, (F) Filamentous, (U) Unicellular

\begin{tabular}{|c|c|c|c|c|c|c|c|c|c|c|c|c|}
\hline \multirow[b]{2}{*}{ Species } & \multicolumn{12}{|c|}{ - Sampling month } \\
\hline & $\mathrm{J}$ & A & $\mathrm{S}$ & $\mathrm{O}$ & $\mathrm{N}$ & $\mathrm{D}$ & $\mathrm{J}$ & $\mathrm{F}$ & M & $\mathrm{A}$ & M & $\mathrm{J}$ \\
\hline Cyanobacteria & & & & & & & & & $a$ & & & \\
\hline Heteroleibleinia pusilla $(\mathrm{F})$ & + & + & + & + & + & + & + & + & + & + & + & + \\
\hline Jaaginema metaphyticum (F) & + & + & + & + & + & + & + & + & + & + & + & + \\
\hline Leibleinia inconspicua $(\mathrm{F})$ & + & + & + & + & + & + & + & + & + & + & + & + \\
\hline Aphanocapsa holsatica (C) & + & + & + & + & + & & + & + & + & + & + & \\
\hline Jaaginema subtilissimun $(\mathrm{F})$ & + & + & & + & + & + & + & + & & & & \\
\hline Synechococcus nidulans (U) & & + & & + & & & + & & & & & \\
\hline Leptolyngbya subtilis $(\mathrm{F})$ & + & + & & + & + & + & + & & & & & \\
\hline Leibleinia epiphytica (F) & + & + & & + & + & & + & + & + & + & + & \\
\hline Calothrix javanica $(\mathrm{F})$ & + & & & & & + & + & + & + & + & + & + \\
\hline Calothrix bharadwajae (F) & + & & & & & & + & + & + & + & + & + \\
\hline Heteroleibleinia rigidula $(\mathrm{F})$ & + & & & & + & + & + & + & + & + & & \\
\hline Heteroleibleinia-Leibleinia epiphytica $(\mathrm{F})$ & & & & & + & + & + & + & + & + & + & + \\
\hline Heteroleibleinia mesotricha $(\mathrm{F})$ & & & & & & + & + & + & + & + & + & \\
\hline \multicolumn{13}{|l|}{ Chlorophyta } \\
\hline Cosmarium sociale $(\mathrm{U})$ & + & + & + & + & + & + & + & + & + & + & + & + \\
\hline Oedogonium sp. aff. sphaerandrum (F) & + & + & + & + & + & + & + & + & + & + & + & + \\
\hline Oedogonium inversum $(\mathrm{F})$ & + & + & + & + & + & + & + & + & + & + & + & + \\
\hline Mougeotia virescens $(\mathrm{F})$ & + & + & + & & + & + & + & + & + & + & + & + \\
\hline Oocystella parva (U or C) & + & + & + & + & + & + & + & + & + & + & + & \\
\hline Monoraphidium subclavatum (U) & + & + & + & + & + & & & & & & & \\
\hline Characium pluricoccum (U) & & & & & + & + & + & + & + & + & + & + \\
\hline Cosmarium subgranulatum (U) & & & & & & + & + & + & + & + & + & + \\
\hline Spirogyra puncticulata $(\mathrm{F})$ & & & & & + & + & + & + & + & + & + & \\
\hline Spirogyra sp. 2 (F) & & & & & + & + & + & + & + & + & + & + \\
\hline \multicolumn{13}{|l|}{ Bacillariophyceae } \\
\hline Gomphonema parvulum/gracile complex (C) & + & + & + & + & + & + & + & + & + & + & + & + \\
\hline Halamphora veneta $(\mathrm{U})$ & + & + & + & + & + & + & + & + & + & + & + & + \\
\hline Navicella pusilla (U) & + & + & + & + & + & + & + & + & + & + & + & + \\
\hline Navicula veneta $(\mathrm{U})$ & + & + & + & + & + & + & + & + & + & + & + & + \\
\hline Nitzschia amphibia (U-C) & + & + & + & + & + & + & + & + & + & + & + & + \\
\hline Cyclotella meneghiniana ( $\mathrm{U}$ or $\mathrm{C}$ ) & + & & + & + & + & + & + & + & + & + & + & + \\
\hline Nitzschia sp. aff. paleacea (U) & + & & + & + & + & + & + & + & + & + & + & + \\
\hline Mastogloia elliptica (U or C) & + & + & + & + & & + & + & + & + & + & + & + \\
\hline Ulnaria acus (U) & & + & + & + & + & + & + & + & + & + & + & + \\
\hline Ulnaria ulna var. ulna (form 1) (U or C) & & + & + & + & + & + & + & + & + & + & + & + \\
\hline Ulnaria ulna var. ulna (form 2) (U or C) & & + & + & + & + & + & + & + & + & + & + & + \\
\hline Achnanthidium sp. (C) & + & + & + & + & + & + & + & & + & & & \\
\hline Rhopalodia gibba (U) & & & & & & + & + & + & + & + & + & + \\
\hline Rhopalodia musculus (U or C) & & & & & & & + & + & + & + & + & + \\
\hline Aulacoseira granulata var. angustissima (U) & & & & & & & & & & & + & + \\
\hline Epithemia adnata (U or C) & & & & & & & & & + & + & + & + \\
\hline Gomphonema truncatum (U) & & & & & & & & & & & + & + \\
\hline
\end{tabular}

crispum (Agardh) Bornet, Lyngbya martensiana Meneghini ex Gomont, and Calothrix javanica De Wildeman-were inhabitants of the lower layer. No secondary epiphytism was developed on the chlorophyte filaments, except on the reproductive parts, where zygotes were being produced.

Although the March perturbations did not lead to physiognomic modifications, these disturbances were related to the appearance of new species, including Epithemia adnata (Kützing) Brébisson and Gom- phonema truncatum Ehrenberg (Table 3), as well as to changes in the abundance of certain taxa already present before the rainfall, characterized by increases in E. sorex Kützing, Cosmarium dybowskii Gutwinski, C. formosulum var. nathorstii (Boldt) West \& West, Mougeotia virescens (Hassall) Borge, Scytonema crispum, and Lyngbya martensiana along with decreases in Rhopalodia musculus, Heteroleibleinia mesotricha (Skuja) Anagnostidis and Komárek, Calothrix javanica, and Oedogonium inversum. 
After the October perturbations, the micro- and macrofauna also started to increase. Chironomid larvae, living in tubes on the bulrushes, appeared in November and reached their maximum in December at Stn 1 (140 tubes per bulrush stem). By January, most of the tubes were empty, and finally, in February, almost none were attached to the bulrush stems. We found neither snails nor shrimp and no signs of grazing activity by those animals. The rhizopods and ciliates were present in low abundances (fewer than 100 ind. $\mathrm{cm}^{-2}$ substrate most of the time), and their principal food, without any selection being evident, was the algae dominant on each sampling date (e.g. Gomphonema spp. and Nitzschia amphibia).

\section{DISCUSSION}

\section{Epiphyton variations in space and time}

Numerous authors have found significant differences in epiphytic-biomass variations over space and time (Cattaneo \& Kalff 1980, Jones \& Mayer 1983, Albay \& Akcaalan 2003, Liboriussen \& Jeppesen 2006, Poulícková et al. 2006, Dos Santos et al. 2008, among others). In Lacombe Lake, the similarity between the 2 sites in relation to epiphyton structure did not coincide with the observations previously reported for other lakes. For example, Roos (1983a,b) and Kairesalo (1983) found, in European lakes, that the epiphyton composition between the central portion of emergent-plant stands (with higher stem densities) and the peripheral zone (with lower stem densities) was different. These authors argued that a more intense influence of climatic conditions (e.g. wind, wave action, and solar radiation) on the border zone was responsible for that difference. Notwithstanding, in Lacombe Lake, the bulrush density in the central part of the stands may well have been insufficiently elevated (<100 stems m ${ }^{-2}$; Cano 2009) to produce differences in periphyton composition and abundance between these 2 sectors. Because the stem densities in the present study were lower than the threshold value defined by Cano (2009) throughout the entire period, we consider that the similarity in environmental conditions resulting from this lower density difference is likely the principal reason why we failed to detect differences between the peripheral and central parts of the bulrush stands.

With respect to time, our analysis of the environmental variables at both of the sampling sites resulted in a discrimination of 3 periods that coincided with the equilibrium states previously identified by
Casco et al. (2009) on the basis of data gathered at 4 sampling points plus a consideration of the biological variables that were necessary for the establishment of equilibrium.

The types of epiphytic communities observed in this seepage lake (single-layered and multilayered) coincided with the turbid- and clear-water states, respectively, and each lasted for a relatively long period. Other authors have found that periphyton communities may have turnover rates of close to $4 \mathrm{wk}$ (e.g. Phragmites australis; Albay \& Akcaalan 2003) or even 2 to 3 wk (e.g. Equisetum fluviatile; Kairesalo 1983). In Lacombe Lake, the single-layered assemblages dominated over a period of 3 mo (the turbidwater period). Next, the multilayered communities maintained themselves without major changes for over 6 mo (the entire clear-water period). Furthermore, as the phaeopigment concentrations and the pigment index indicated, both types of communities remained in a relatively good physiological state with no accumulation of senescent organisms. These findings suggest that periphyton communities may become quite stable, even in the face of perturbations. Moreover, even though the August and March precipitations during the turbid- and clear-water periods, respectively, may have compromised this stability, the physiognomies, species compositions, and physiological state of the assemblages persisted after those perturbations. Thus, the periphyton presented a dual-period variation pattern (i.e. turbid to clear) in contrast to the 3-period dynamic observed by Casco et al. (2009) for the phytoplankton.

\section{Factors that affect epiphyton biomass and composition}

The variation in the epiphytic community parameters during the study period coincided in time with (1) the gradual changes over the entire year from conditions of greater turbidity and conductivity along with higher TP concentrations to clearer water with lower conductivity and nutrient concentrations and (2) the October perturbations related to underwater light-climate improvement and an increase in the TP levels (Cano et al. 2008). This relationship, together with the absence of signs of high grazing pressure, suggest that the key influences structuring the epiphyton assemblages in Lacombe Lake were environmental variables. The scarce amount of grazing recorded may be related to the central location of the Schoenoplectus stands and the particular physiognomy of those plants, which forms a poor refuge for 
invertebrates and omnivorous fish from predators. Our results are in agreement with those of Meerhoff et al. (2007), who speculated that the biomass of periphyton from submerged and floating macrophytes in subtropical lakes is controlled more by environmental variables (temperature, light, nutrients) than by shrimp grazing or the physical damage produced by omnivorous fish.

\section{Light}

Underwater light availability varies with radiation intensity and photoperiod throughout the year but is also related to phytoplankton density (Lowe 1996, Liboriussen \& Jeppesen 2006), the amount of detritus and inorganic suspended solids (Scheffer 1998), and the presence of submerged and emergent macrophytes (Kiss et al. 2003). In Lacombe Lake, during the first 3 mo of our study, lower epiphyton biomass values and a lower species richness and evenness, and thus a lower diversity index, all coincided with the higher phytoplankton (chl a) concentrations that promoted a turbid period (Cano et al. 2008, Casco et al. 2009). The biomass peaks of phytoplankton and epiphytic communities have been generally found not to overlap in time (Roos 1983a, Hodgson et al. 1986, Karosiene \& Kasperoviciene 2008, Sánchez et al. 2010). As a possible explanation with respect to our study, the effect of phytoplankton overshadowing on the epiphytic community might have initially been pronounced during the turbid-water period, but upon the development of the submerged-macrophyte stands between September and October, the light climate later became more favorable for epiphyte growth. Because the density of emergent macrophytes and the cover of submerged plants were low at both of the sampling sites, their shadowing influence on epiphytic growth was even more unlikely.

\section{Nutrients}

Nutrient concentrations are a crucial variable for the quantity and quality as well as the spatial and seasonal distribution of periphyton in lentic environments (Lowe 1996). Epiphytic biomass increments occurred in conjunction with the TP concentration peaks in October and November. In some temperate lakes, a larger biomass of filamentous chlorophytes has been related to higher TP levels in water (Cattaneo 1987). A similar relationship was observed in Lacombe Lake, as manifested by an increment in the density and biovolume of Oedogonium sp. aff. sphaerandrum and Stigeoclonium sp. aff. tenue in October and of Oedogonium inversum and Spirogyra species in November.

The concentrations of TP (and in particular its soluble reactive fraction), total inorganic $N$, and reactive silica recorded throughout the study period may not have been limiting for algal development at any time (Cano 2009). High concentrations of TP were found to coincide with lower epiphytic biomasses during the more turbid period. This fact suggested that the epiphytic biomass development in October was probably more strongly dependent on the improvement in the light climate at that time. Increments of TP in the water may have simply helped to enhance the light-climate-related growth stimulation. Consistent with this notion, Liboriussen \& Jeppesen (2006) proposed that periphyton production depended on a combination of both nutrients and light availability when the epiphytes had access to the same type of substrate within the water column in 2 temperate lakes.

In Lacombe Lake, the decrease in TP from November onward coincided with increases in the epiphyte total biovolume, mean biovolume per individual, and biomass (measured as chl a content). The decline in TP also coincided with an increment in the bulrush stem densities at Stn 1 and the submergedmacrophyte growth at both sites. These biomass increases, also benefited by temperature conditions and light improvement, might be a manifestation of the subsequent utilization of the earlier phosphorus peak by the primary producers of the ecosystem.

\section{Submerged plant surface available for epiphyte colonization}

The SECS may vary in accordance with the water level as well as with the growth or death of the host plant. Peterson (1996) pointed out that perturbations operating on a large scale, such as an abrupt rise in water level, might significantly alter the density and taxonomic composition of the pool of immigrant species. The increases in water level during August and March made a large amount of newly submerged plant surface available for epiphyte colonization, constituting a resource ready for use (Lowe 1996). New opportunities may have been generated for not only the species that were already present but also the immigrants from other communities or even from other lakes. Nevertheless, after both of the waterlevel increases in August and March, the characteris- 
tics of the taxonomic composition and the physiognomy of the communities remained essentially similar to those that had been recorded in the months prior to those precipitations. The change in the epiphytic communities started to occur after the October rainfall, when the increase in water level was not as high as those recorded during August and March. At this time, the underwater light climate became more favorable, and the temperature and TP concentrations increased. Substrate availability (from the macroscopic standpoint) may be relevant to periphyton development when that resource is scarce. Although 2001 to 2002 may not have been a high-production year for bulrushes in Lacombe Lake, this resource cannot be considered as scarce. Consequently, the substrate availability at a macroscopic scale per se did not bring about the community change in October, although the effects of this resource may have combined with the influence of increased amounts of light and nutrients subsequent to the critical rainfall. Moreover, the communities present before the perturbations were capable of subsequently reorganizing themselves, both on the already colonized surface and on the newly available areas, without significantly altering their architecture or taxonomic composition.

\section{CONCLUSIONS}

The intensity of a perturbation coupled with the resilience of the community that has developed previously is a critical consideration because, after the disturbance, communities that are relatively stable sensu Holling (1973) will tend to reorganize themselves within the new submerged available surface in much the same manner as they had been organized before the intervention.

The most significant finding of this investigation is that epiphyton assemblages can maintain a degree of relative stability after disturbances for prolonged periods of time, in spite of their members' inherent ability to reproduce rapidly and the consequent possibility of rapid changes in epiphytic community structure and functioning in response to perturbations. Two stable communities, moreover, coincided with the 2 stable states developed at the subtropical Lacombe Lake. The epiphyton variables correspond to the major changes at the systemic level, although less closely than did the phytoplankton community, which responded in a 3-phase pattern of variation. The passage from one type of epiphytic community to another at Lacombe Lake occurred within the con- text of a radical change in environmental variables that consisted of a long-lasting improvement in the light climate and temporary increase in nutrients related to the heavy rainfall in October.

Acknowledgements. This work was supported by CONICET and UNLP funds and fellowships. We thank M. E. Mac Donagh, L. Solari, and M. Ardohain for their help during field and laboratory work and are particularly grateful to M. E. Mac Donagh for her advice in statistical matters. We are especially thankful to J. Toja for letting us use the PRIMER 5.2.9 statistical package with her permission and are grateful to D. F. Haggerty, a retired career investigator and native English speaker, for editing the final version of the manuscript. We also thank the 3 anonymous reviewers for the constructive suggestions and comments aimed at the improvement of the manuscript.

\section{LITERATURE CITED}

Acker F (2002) Protocol P 13-50: preparation of USGS NAWQA Program algal samples for analysis using Palmer Maloney cells. In: Charles DF, Knowles C, Davis RS (eds) Protocols for the analysis of algal samples collected as part of the US Geological Survey National Water-Quality Assessment Program. The Academy of Natural Sciences of Philadelphia (ANSP), Patrick Center for Environmental Research, Phycology Section, Report No. 02-06, Philadelphia, PA, p 55-60

- Albay M, Akcaalan R (2003) Comparative study of periphyton colonisation on common reed (Phragmites australis) and artificial substrate in a shallow lake, Manyas, Turkey. Hydrobiologia 506-509:531-540

> Boero F, Belmonte G, Fanelli G, Piraino S, Rubino F (1996) The continuity of living matter and the discontinuities of its constituents: Do plankton and benthos really exist? Trends Ecol Evol 11:177-180

- Burkholder JM, Wetzel RG (1989) Microbial colonization on natural and artificial macrophytes in a phosphoruslimited, hardwater lake. J Phycol 25:55-65

Cano MG (2009) Fitoperifiton de un lago somero y su relación con los estados de biequilibrio. PhD dissertation, La Plata University

> Cano MG, Casco MA, Solari LC, Mac Donagh ME, Claps MC (2008) Implications of rapid changes in chlorophyll-a of plankton, epipelon, and epiphyton in a Pampean shallow lake: an interpretation in terms of a conceptual model. Hydrobiologia 614:33-45

> Casco MA, Mac Donagh ME, Cano MG, Solari L, Claps MC, Gabellone N (2009) Phytoplankton and epipelon responses in clear and turbid phases in a seepage lake (Buenos Aires, Argentina). Int Rev Hydrobiol 94:153-168

Cattaneo A (1987) Periphyton in lakes of different trophy. Can J Fish Aquat Sci 44:296-303

Cattaneo A, Kalff J (1980) The relative contribution of aquatic macrophytes and their epiphytes to the production of macrophyte beds. Limnol Oceanogr 25:280-289

Dos Santos A, Cano MG, Casco MA (2008) Contenido clorofílico del epifiton sobre Scirpus californicus en la laguna La Rosita (Partido de Castelli). Biol Acuat 24: 149-156

Goldsborough LG, Robinson GGC (1996) Patterns in wetlands. In: Stevenson RJ, Bothwell ML, Lowe RL (eds) 
Algal ecology: freshwater benthic ecosystems. Academic Press, San Diego, CA, p 77-117

Hansson LA (1992) Factors regulating algal biomass. Limnol Oceanogr 37:322-332

Hodgson LM, Linda SB, Canfield D Jr (1986) Periphytic algal growth in a hypereutrophic Florida Lake following a winter decline in phytoplankton. Fla Sci 4:234-241

Holling CS (1973) Resilience and stability of ecological systems. Annu Rev Ecol Syst 4:1-23

Jones RC, Mayer KB (1983) Seasonal changes in the taxonomic composition of epiphytic algal communities in Lake Wingra, Wisconsin, USA In: Wetzel RG (ed) Periphyton of freshwater ecosystems. Dr. W. Junk Publishers, The Hague, p 11-16

Kairesalo T (1983) Dynamics of epiphytic communities on Equisetum fluviatile L. In: Wetzel RG (ed) Periphyton of freshwater ecosystems. Dr. W. Junk Publishers, The Hague, p 153-160

Karosiene J, Kasperoviciene J (2008) Seasonal sucession of epiphyton algal communities on Phragmites australis (Cav.) Trin. ex Stend. in a mesotrophic lake. Ekologija 54:32-39

Kiss MK, Lakatos G, Borics G, Gido Z, Deák C (2003) Littoral macrophyte-periphyton complexes in two Hungarian shallow waters. Hydrobiologia 506-509:541-548

Liboriussen L, Jeppesen E (2006) Structure, biomass, production and depth distribution of periphyton on artificial substratum in shallow lakes with contrasting nutrient concentrations. Freshw Biol 51:95-109

Lowe RL (1996) Periphyton patterns in lakes. In: Stevenson RJ, Bothwell ML, Lowe RL (eds) Algal ecology: freshwater benthic ecosystems. Academic Press, San Diego, CA, p $57-76$

Lund JW, Kipling C, Le Cren ED (1958) The inverted microscope method of estimating algal number and the statistical basis of estimations by counting. Hydrobiologia 11: 143-170

Margalef R (1974) Ecología. Ediciones Omega, Barcelona

Meerhoff M, Clemente JM, Teixeira De Mello F, Iglesias C, Pedersen AR, Jeppesen E (2007) Can warm climaterelated structure of littoral predator assemblies weaken the clear water state in shallow lakes? Glob Change Biol 13:1888-1897

Modenutti B, Balseiro E (1995) Muestreos y error. In: Lopretto E, Tell HG (eds) Ecosistemas de aguas continentales. Metodologías para su estudio. Ediciones Sur, La Plata, p 351-360

Peterson CG (1996) Response of benthic algal communities to natural physical disturbance. In: Stevenson RJ, Bothwell ML, Lowe RL (eds) Algal ecology: freshwater benthic ecosystems. Academic Press, San Diego, CA, 375-402

Polis GA, Anderson WB, Holt RD (1997) Toward an integration of landscape and food web ecology: the dynamics of spatially subsidized food webs. Annu Rev Ecol Syst 28: 289-316

Editorial responsibility: Carolyn Burns, Dunedin, New Zealand
Poulícková A, Kitner M, Hasler P (2006) Vertical distribution of attached algae in shallow fishponds of different trophic status. Biologia 61:1-9

Ramírez B (2005) Distribución vertical de clorofila en los fiordos australes ubicados entre el estrecho de Magallanes y el Cabo de Hornos (Chile). Cienc Tecnol Mar (Valpso) 28:43-61

Rodríguez P, Tell G, Pizarro H (2011) Epiphytic algal biodiversity in humic shallow lakes from the Lower Paraná River Basin (Argentina). Wetlands 31:53-63

Romo S, Galanti G (1998) Vertical distribution of epiphytic algae on water chesnut (Trapa natans). Arch Hydrobiol 141:483-504

Roos PJ (1983a) Dynamics of periphyton community. In: Wetzel RG (ed) Periphyton of freshwater ecosystems. Dr. W. Junk Publishers, The Hague, p 5-10

Roos PJ (1983b) Seasonal changes in diatom-structure of periphyton from two localities in Lake Maarsseveen: community indices. In: Wetzel RG (ed) Periphyton of freshwater ecosystems. Dr. W. Junk Publishers, The Hague, p 59-61

> Rott E (1981) Some results from phytoplankton counting intercalibrations. Aquat Sci 43:34-62

Sánchez ML, Pizarro H, Tell G, Izaguirre I (2010) Relative importance of periphyton and phytoplankton in turbid and clear vegetated shallow lakes from the Pampa Plain (Argentina): a comparative experimental study. Hydrobiologia 646:271-280

Scheffer M (1998) Ecology of shallow lakes. Chapman \& Hall, London

Scheffer M, Hosper SH, Meijer ML, Moss B, Jeppesen E (1993) Alternative equilibria in shallow lakes. Trends Ecol Evol 8:275-279

Schindler DE, Scheuerell MD (2002) Habitat coupling in lake ecosystems. Oikos 98:177-189

Schoeman FR, Archibald REM, Ashton PJ (1984) The diatom flora in the vicinity of Pretoria Salt Pan, Transvaal, Republic of South Africa. Part III. S Afr J Bot 3:191-207

Strayer D, Likens GE (1986) An energy budget for the zoobenthos of Mirror Lake, New Hampshire. Ecology 67:303-313

Tur NM, Rossi JB (1976) Autoecología de Scirpus californicus. 1. Crecimiento y desarrollo de la parte aérea. Bol Soc Argent Bot 17:73-82

- Vadeboncoeur Y, Vander Zanden MJ, Lodge DM (2002) Putting the lake back together: reintegrating benthic pathways into lake food web models. Bioscience 52: 44-54

Vander Zanden MJ, Chandra S, Park SK, Vadeboncoeur Y, Goldman CR (2006) Efficiencies of benthic and pelagic trophic pathways in a subalpine lake. Can J Fish Aquat Sci 63:2608-2620

Varela M (1981) El problema de la determinación de clorofila a en el fitobentos: discusión sobre la metodología. Oecol Aquat 5:7-19

Submitted: July 29, 2011; Accepted: January 20, 2012 Proofs received from author(s): March 30, 2012 